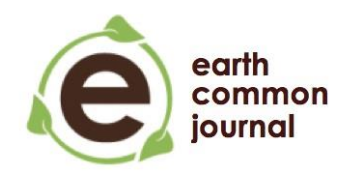

Earth Common Journal

Convergence

MacEwan University

Volume 5, Number 1, September 2015

\title{
Article
}

\section{Breaking the Cycle: Changing Alberta in the present to save the future}

\author{
A. Rachelle Foss \\ MacEwan University, Canada
}

\begin{abstract}
Alberta's resource power lies within the energy sector; in particular, the oil and gas industry. However, this same energy sector is contributing heavily to the destruction of the landscape and is contaminating the environment. This destructive pattern may seem unrelated to the province's economy, but a closer look shows that they are, in fact, closely connected. This is largely due to a failure by both the industry and political leaders to have a vision for the economic future. Although oil and gas royalties, paid to the province for the right to use crown land for capital gain, provide considerable financing to support Alberta's infrastructure, redirecting a large portion of those royalties back into the energy sector has contributed to the provincial budget surplus plummeting into a budget deficit. Couple this with a consistent failure to impose environmental accountability on heavily polluting energy companies and limited support for sustainable energy practices and innovations. Continuing on this path is a short sighted plan that puts both the Alberta and Canadian economies at risk as they fail to diversify and move forward with the rest of the world as it makes changes toward reducing emissions and increasingly supports ecological practices. Instead, Alberta must shift their focus away from the tradition of investing in the oil industry and, as many other regions worldwide have done, invest in renewable resources, sustainable practices, and increase support for local energy innovations to ensure the province's energy sector, environment, and economy move towards a strong future.
\end{abstract}




\section{Introduction}

Against a horizon blotted by billowing smog, monumental machinery move across a stripped terrain, each piece of colossal construction equipment consuming up to 400 Litres of fuel every day (Foss, June 12, 2015, interview). Once lush Canadian muskeg and boreal forest, the barren landscape is now scarred by expansive access roads that run between the countless sludgy tailings ponds gouged into the earth. Anyone who has ever witnessed this dramatic and deleterious change in the landscape knows that this is the environmental face of Alberta's long established relationship with the oil and gas industry — and it could also serve as a metaphor for Canada's economic relationship with the same business.

While the long term cost to the environment has remained seemingly unrelated to the province's economic climate, we are beginning to see where the two areas have now converged demonstrating a potentially bleak future for both the province's environment and economy, but also the possibility of leaving behind the status quo and focusing on new directions, potentially leading to triumphs in areas of both economics and the environment. Not only are the economics of the current system unsustainable over the long term, as seen by the fallout of the recent downturn within the oil and gas industry, there is a clear lack of vision by those doing the damage when it comes to the effects on the northern Alberta landscape, the wildlife, and as Cariou and McArthur (2009) examined, the health of the First Nations communities within the region.

\section{Alberta's Energy Sector}

For decades, both the provincial and the federal governments have aggressively promoted the oil and gas industry in Alberta, and, in exchange, the province is reimbursed through a royalty system for the right to use Crown land for capital gain. According to a publication by Energy Alberta,

Companies are granted the right to explore for and develop petroleum and natural gas resources, in exchange for the value to Albertans that flows from development in the form of royalties, bonus bid payments (the amount of money offered or bid for the mineral rights) and rents (2012, para. 3).

As a large part of funding the province's healthcare, infrastructure, and education systems, Energy Alberta notes that, "royalties are an important part of the Alberta government's revenue stream" (Energy Alberta, 2012, para. 1). And while it can't be denied that payments are currently a significant part of the provincial economy, Rubin (2015) points out that this overlooks the fact that a large portion of these royalties are put back 
Towards financing the so-called Alberta Advantage, part of which included a flat 10 per cent personal income tax rate and no provincial sales tax. In theory, such choices are designed to attract other industries to the province ... in practice, the main beneficiary of the province's policy decisions, as ever, is Alberta's oil industry (para. 4).

However, the fact that Alberta offers 'the lowest royalties almost in the world" (Hussain, Morgan, 2015, para. 4), according the NDP leader Rachel Notley, is not the only failing within the system. There are a number of other, possibly more costly, flaws. One of these seems to be a consistent case of shortsightedness-from both an economic and an environmental standpoint.

The 2014 collapse within the oil industry, which, according to the Energy Information Administration, was due, in part, to a global oversupply - the oil reserve hit the highest it has been in over 80 years (Menton, 2015, para. 9). This surplus in the global oil market deeply affected the Alberta economy, turning "a once-enviable budget surplus into a monster \$5-billion deficit” (Rubin, 2015, para. 1), affecting countless jobs within the energy sector. According to a Statistics Canada analyst, "by early January 2015, 13,000 jobs were lost in the Alberta's natural resource sector since September 2014. The majority of those jobs were in oil and gas" (Geddes, 2015, para. 4). In an article by Geddes (2015), tracking the impact, as of "January, [2015], the Canadian Association of Oilwell Drilling Contractors predicted 167 fewer drilling rigs in the field compared to 2014, resulting in the layoffs of 3,400 rig workers with the loss of another 19,500 indirect jobs" (para. 5). Although the industry has seen a minute recovery this year, in May 2015 companies in the energy sectors were still reporting losses in the tens of millions and job cuts (para. 6) to "as many as 2,000 employees from its North American workforce, including close to 800 in Canada" (para. 6). However, this economic issue was not isolated to Alberta.

When the province's oil and gas industry collapsed the federal government was unable to provide funding to stop the economic nose-dive, because, according to then-premier Jim Prentice, "'It's the Alberta economy that has been driving the national economy in this country for more than a decade, and in fact Alberta has accounted for more than $50 \%$ of the jobs that have been created in Canada over the last decade or more," (Cattaneo, 2015, para. 14). Because of that, Alberta's fiscal decline has also adversely affected Canada's federal budget. (Cattaneo, 2015, para. 13).

Recently, as the province's energy sector slowly regains its footing within the market, fresh industry fears, illustrated by plummeting energy stocks following the May 2015 election, have arisen around the newly elected provincial NDP government and its talk of 
increasing royalty rates (Hussain \& Morgan, 2015, para. 1 \& 2). Worries that increased rates will drive capital away from the province and kill all hopes of recovery within an already precarious oil sector (para. 1) are in part fuelled by memories of the failed attempt in 2007, by then premier Ed Stelmach, to increase royalties. The increases sparked an exodus of investors out of Alberta, injuring the provincial economy and Stelmach was eventually pressured into reversing almost all of his increases (para. 10). Current industry fears are compounded by a talk of ending "the PC practice of spending government dollars to promote flagship pipelines on behalf of the industry" (para. 15). But these concerns are limited, failing to look at the long-term effects of barreling blindly down the same path. Nevertheless provincial and federal economics are not the only issue to be addressed regarding the energy industry.

\section{Lacking Accountability}

The clear lack of accountability within the fossil fuel industry regarding the environment they are ravaging for capital gain is astounding. As Berman (2012) notes in her article on energy companies' attempts to mask the pollution within the oil sands,

There are still no laws governing the amount of toxins spewed into the water. There's no plan to reduce global warming pollution. There are no hard limits around the amount of water that can be withdrawn from the Athabasca River, yet the oil sands are allowed to divert from the river the equivalent of seven times the annual water use by the city of Edmonton (para. 8).

Instead of investing in potential solutions - which do currently exist — the industry spends millions of dollars on persuasive advertising to create an impression of successful solutions. Tailings pond management, for example, "remains one of the most difficult environmental challenges for the oil sands mining sector. There is currently about 77 square kilometres of oil sands tailings ponds water in Alberta" (Alberta Government, 2014, para. 1). The loser in that equation is often the wildlife in the area, as demonstrated "in 2008, [when] 1,600 ducks died on a nearby Syncrude tailings pond, pushing the ponds issue into international headlines" (Pratt, 2013, para. 7). Those were the bird deaths that were reported.

Regarding existing tailings, Suncor has recently started reclamation of tailings areas, such as Wapisiw Lookout. However, the company acknowledges that "the challenge of reclaiming a tailings pond in the Alberta oil sands has never been accomplished before" (Suncor, 2014, para. 5) and that the project, which essentially entail filling the tailings pond in with dirt and replanting the area, could be a two-decade long experiment-that may 
fail. The toxicity of the area prior to it being covered with dirt is the biggest challenge: dirt that is now at risk of becoming contaminated as well.

According to an interview Tzeporah Berman (2012) had with one industry executive, companies have the technology to eliminate new tailings but "won't deploy [it] until regulation forces all companies to do so, creating a level playing field" (para. 10). Confirmation that the technology does exist came about in 2014, when 17-year-old, Calgary high school student, Hayley Todesco, became "the Google Science Fair's regional winner for Canada" (Chung, 2014, para. 2), with her technology that uses sand and bacteria to clean up hazardous waste generated by oil sands extraction. Hayley's method has the potential to promote deterioration of compounds 14 times faster than in tailings (Chung, 2014, para. 4).

Nevertheless, the industry's misdirection of funds from action into advertising is not surprising considering that in 2013 , the federal government spent an estimated " $\$ 40$ million ... to advertise Canada's natural resource sector — principally oil and gas — at home and abroad" (The Canadian Press, 2013, para. 1). In 2014, the federal government "tapped an international public relations firm to roll out a $\$ 22$ million advertising campaign promoting the oilsands and Canada's natural resource sector across the world" (Boutilier, 2014, para. 1). But the most astonishing aspect of those numbers is that the government is currently not supporting renewable energy sources to the extent they are selling themselves to be-regardless of promises they are making. According to Ed Whittingham (2012), of the Pembina Institute,

In January 2012 the government committed $\$ 195$ million over 5 years to ecoENERGY Efficiency Initiatives, [however], no new energy efficiency initiatives were identified in the 2012 budget, and the ecoENERGY Retrofit-Homes program (which encouraged efficiency improvements in Canadian homes), was unexpectedly wrapped up early [the same] year (para. 17).

But the government has been selling Canada worldwide as a "clean energy superpower" (Whittingham, 2012, para. 1); however, this is simply an effective sales pitch. Perceptually it is effective-placing Canada in the $12^{\text {th }}$ position in the category of how people thought the country performed (Dual Citizen LLC, 2014, p. 12), on the Global Green Economy List (GGEL), which is the measure of a country's performance on "Leadership and Climate Change, Efficiency Sectors, Markets and Investments, and Environment and Natural Capital" (p. 11). But, in fact, in 2014, Canada's actual performance ranked far below $12^{\text {th }}$ place in $29^{\text {th }}$ position (p. 12), below the United States-which houses several states, including Florida, "where it is illegal to sell power from any source other than 
electric utilities" (Sheppard, 2015, para. 3). But what is more frustrating is that many of these countries that out ranked Canada on the GGEL are Scandinavian countries that face similar geographic challenges including colder climates and limited sun.

\section{Embracing Environmentalism}

However, there are signs that Canadians are beginning to embrace environmental practices, regardless of the cancelled energy initiatives program. In 2009 Toronto, Ontario, began a mandate necessitating and governing the installation of green roofs in both industrial and residential buildings in the city (City of Toronto, 2015, para. 1). The bylaw applies to new building permit applications for residential, commercial, institutional and industrial developments (para. 2). Considering the benefits, the implications of encouraging green rooftops across Canada are extraordinary, because "Green roofs have an isolating effect, helping reduce the amount of energy needed to heat a building in winter and cool it in summer" (Aggence France-Presse, 2015, para. 2). Green roofs also promote ecology within a metropolitan landscape because they "retain rainwater, thus helping reduce problems with runoff, while favouring biodiversity and giving birds a place to nest in the urban jungle" (para. 3). According to Construction Canada, other Canadian cities are adopting the practice without being mandated. In 2013 the "top five Canadian cities reporting the most area of vegetated roofs installed [were] Toronto, Montréal, Québec City, Halifax-Dartmouth, and Edmonton" (Construction Canada, 2013, para. 3). This kind of proactive action on the part of Canadians is encouraging and, despite the government's lax approach may work to move Canada into the running with countries like France, whose environmental responsibility is at an impressive level.

Not only will Paris host the 2015 United Nations conference on climate change, the country is working towards a goal to reduce a quarter of its emissions and energy usage by

2020 (Carrasco, 2015, para. 1). In their efforts to meet these goals, not only has the Eiffel Tower been fitted with wind turbines (para. 1), a newly approved law requires "Rooftops on new buildings built in commercial zones in France must either be partially covered in plants or solar panels" (para. 1).

Europe is not the only region begin taking advantage of renewable resources and energy efficiency. Lawmakers in Chico, California, have installed solar panels on the city's properties. The "reliable on-site solar photovoltaics (PV)... harnesses sunlight to generate emissions-free electricity, as well as stabilize the municipality's utility bills ... [and power] its Water Pollution Control Plant ...making Chico one of the largest municipal users of solar generated power (SunPower, 2015, para. 2, 3). While solar power has come a long 
way in many areas, it is true that it still comes with its own set of challenges in many municipalities, one of which is storing excess energy generated.

For more than a century the energy infrastructure has operated on a network of wires and poles that were developed to transfer fossil fuel energy (Williams, 2014, para. 3). This means “Today's power grid isn't able to store energy. As it's generated it flows through transmission wires to local utilities that deliver the power to homes and businesses in your neighborhood" (para. 4), but "solar energy for example is only generated during the day and any excess energy goes back to the grid" (Wallace, 2015, para. 4). However, Tesla has developed a promising new technology that will help overcome this particular challenge to solar energy users.

Tesla CEO, Elon Musk, has unveiled the company's design for a new battery that could offer homeowners a primary source of power and efficient renewable energy storage (para. 1,4). This means that the "Tesla battery will offer a way to store the excess power generated so that you can use it at another time" (para. 5). As communities move towards "solar energy, [this means] a lot more of your devices could be kept charged up for free in the near future" (para. 4).

Although, the amount of "sunlight that hits the Earth in just one hour is enough to power the world for an entire year" (Williams, 2014, para. 6), the energy captured is irregular based on time of day and cloud cover. However, by utilizing a solar energy "system that tracks and adjusts with the sun's movement would have a maximum efficiency of 85 percent, while a stationary system would have a maximum efficiency of 55 percent" (para. 7). It is on this premise that Calgarian Eden Full developed her SunSaluter innovation:

A low-cost, low-tech device that uses gravity and a couple water bottles to make a solar panel follow the sun, increasing energy output by 40 per cent. Intended to help provide small-scale, affordable clean energy in the developing world, the SunSaluter has now been installed in 16 countries and counting (Ostroff, 2015, para. 4).

All these advancements in both performance and storage of solar energy are promising for the future, and should take more precedence in a province like Alberta. Not only is the province home to a number of amazing innovators, but because the complex relationship the province has with the fossil fuel industry is changing whether or not the province keeps up. 


\section{Looking to the Future}

If both Alberta and the Canadian federal government were forecasting into the future, they would see that "nearly a decade of evidence that shows the high crude prices counted on by the oil sands industry aren't compatible with healthy global economic growth." (Rubin, 2015, para. 6). Although the fossil fuel industry is beginning to recover from the 2014 collapse, there are many signs that warn of a potential recurrence in the near future. Not only do current talks between Iran and the United States promise to once again affect the global oil supply, as early as 2016 (Yep, 2015, para. 5), Alberta's resistance to changing the status quo is no longer prudent.

Global moves to reduce emissions and the deleterious effects of the energy industry on the environment, is “troubling for Alberta's oil industry, as well as future provincial budgets, [as countries make] the global move towards reducing carbon emissions" (para. 8). Although there is not currently "a binding global agreement" (para. 8) in place, a number of countries have already taken steps toward reductions, particularly in the coal industry. This move has hurt the coal industry as a whole. So it is especially shortsighted on the Canadian and Alberta governments' part to put blinders on to what is happening in the coal industry and assume that the oil and gas industry will not be the next target. Jeff Rubin (2015) notes in his article on the province's reliance on oil and gas revenue that

According to the International Energy Agency, the fight against climate change means world oil demand will need to peak in the next five years and then start falling considerably in order to keep atmospheric carbon from reaching even more dangerous levels (para. 9).

With a struggling energy sector, many global models for renewable resources and sustainability, in addition to local innovations, and a new NDP government that promises to change the norms in place from decades of PC leadership. Things are aligning for the province to begin to turn away from such a deep investment in the oil industry and begin to support renewable resources, sustainable practices, and the innovations that have the potential to revolutionize the province's energy industry and prepare for the future.

* Author: A.R. Foss is a recent graduate of the Bachelor of Applied Communications in Professional Writing, from MacEwan University. She has worked as a writer and editor for The Western Sentinel and as a copy editor for NAIT, and is now freelancing. She has published an article in each edition of the Earth Common Journal since its inangural year in 2011. 


\section{References}

Agence France-Presse. (2015, March 20). France decrees new rooftops must be covered in plants or solar panels. The Guardian. Retrieved from http://www.theguardian.com/world/2015/mar/20/france-decrees-new-rooftopsmust-be-covered-in-plants-or-solar-panels

Alberta Government. (2014). Tailings. Retrieved from http://oilsands.alberta.ca/tailings.html

Boutilier, Alex. (2014, January 9). Ottawa hires ad firm for $\$ 22$ million oilsands campaign. The Star. Retrieved from http://www.thestar.com/news/canada/2014/01/09/ottawa_hires_ad_firm_for_22 _million_oilsands_campaign.html

Cattaneo, Claudia. (2015, January 15). No help from Ottawa as Alberta's economy devastated by oil collapse. Financial Post. Retrieved from http://business.financialpost.com/news/energy/no-help-from-ottawa-as-albertaseconomy-devastated-by-oil-collapse?__lsa $=$ e657-2a37

Cariou, Warren, and Neil McArthur (Writers), Warren Cariou \& Neil mcArthur (Producer \& Director).(2009). Land of Oil and Water. [DVD]. Canada.

Carrasco, Alexa. (2015, March 25). New French Law Forces Buildings to Plan for Green Roofs. Curbed. Retrieved from http://curbed.com/archives/2015/03/26/francelaw-green-roofs.php

Chung, Emily. (2014, July 11). Calgary's Hayley Todesco wins Canadian Google Science Fair prize. CBC News. Retrieved from http://www.cbc.ca/news/technology/calgary-s-hayley-todesco-wins-canadiangoogle-science-fair-prize-1.2704257

City of Toronto. (2015). Green Roof Bylaw. Retrieved from http://www1.toronto.ca/wps/portal/contentonly?vgnextoid $=83520621 \mathrm{f} 3161410 \mathrm{~V}$ gnVCM10000071d60f89RCRD\&vgnextchannel=3a7a036318061410VgnVCM1000 0071d60f89RCRD

Construction Canada. (2013, May 15). North American green roof industry growing. Retrieved from_http://www.constructioncanada.net/north-american-green-roofindustry-growing/ 
Energy Alberta. (September 2012). Talk About Royalties. Retrieved from http://www.energy.alberta.ca/Org/pdfs/FS_Royalties.pdf

Geddes, Lisa. (2015, May 13). Timeline: tracking the layoffs in Alberta's oilpatch. Global News. Retrieved from http://globalnews.ca/news/1889598/timeline-tracking-thelayoffs-in-albertas-oilpatch/

Henton, Darcy. (2015, June 16). Notley issues fiery stance on pipeline position in first NDP question period. Calgary Herald. Retrieved from http://calgaryherald.com/news/politics/notley-issues-fiery-stance-on-pipelineposition-in-first-ndp-question-period

Hussain, Yadullah and Geoffrey Morgan. (2015, May 7). Alberta oil industry fears world's 'lowest royalties' threatened by new NDP government. Financial Post. Retrieved from http://business.financialpost.com/news/energy/alberta-oilindustry-fears-world-lowest-royalties-threatened-by-new-ndpgovernment?_lsa $=\mathrm{e} 657-2 \mathrm{a} 37$

Menton, Jessica. (2015, March 16). Why Are Oil Prices Falling? Here Are Four Reasons Crude Prices Continue To Trend Lower. International Business Times. Retrieved from http:/ / www.ibtimes.com/why-are-oil-prices-falling-here-are-four-reasonscrude-prices-continue-trend-lower-1848742

Ostroff, Joshua. (2015, April 22). These Eco-Inventions Are Canada's Earth Day Gifts To the World. Huffington Post. Retrieved from http://www.huffingtonpost.ca/2015/04/22/canadian-inventionsenvironment_n_7111298.html

Pratt, Sheila. (2013, December 7). Tailings ponds: The long-term liability of the oilsands. Edmonton Journal. Retrieved from http://www.edmontonjournal.com/business/Tailings+ ponds+long+term+liability +oilsands+with+video/9252123/story.html\#_ffederated $=1$

Rubin, Jeff. (2015, March 30). The sooner Alberta weans itself from its resource addiction, the better. The Globe and Mail. Retrieved from http://www.theglobeandmail.com/report-on-business/industry-news/energy-andresources/the-sooner-alberta-weans-itself-from-its-resource-addiction-thebetter/article23681511/

Sheppard, Kate. (2015, March 9). Conservative Groups Battle Over Solar In Florida. Huffington Post. Retrieved from 
http://www.huffingtonpost.com/2015/03/09/florida-solarconservatives_n_6834792.html

Suncor. (2014). "Wapisiw Lookout Reclamation". Retrieved from http://www.suncor.com/en/responsible/3708.aspx

SunPower Corporation. (2015). City of Chico Generates Clean Solar Energy. Retrieved from http://us.sunpower.com/commercial-solar/case-studies/city-of-chico/

The Canadian Press. (2013, November 27)._Oil and gas ad campaign cost feds $\$ 40 \mathrm{M}$ at home and abroad. CBC News Retrieved from http://www.cbc.ca/news/politics/oil-and-gas-ad-campaign-cost-feds-40m-athome-and-abroad-1.2442844

Wallace, Alyn. (2015, February 17). New Tesla battery will power your entire home, for free. Interesting Engineering. Retrieved from http:/ /interestingengineering.com/tesla-new-battery-forhome/\#sthash.q6weS6bt.dpuf

Williams, Brittany. (2014, May 19). The 3 Challenges Solar Energy Needs to Overcome to Continue its Growth. Solarenergy.net. Retrieved from http:/ / solarenergy.net/News/3-challenges-solar-energy-needs-overcome-continuegrowth/

Wittingham, Ed. (2012, March 30). “Budget 2012: Canada won't spare a penny for clean energy". Pembina Institute. Retrieved from http://www.pembina.org/blog/616

Yep, Eric. (2015, April 2). How Iranian Nuclear Deal Would Affect Oil Markets. The Wall Street Journal. Retrieved from http://www.wsj.com/articles/how-iraniannuclear-deal-would-affect-oil-markets-1428032400 